\title{
Alina Rynio
}

\section{PATRIOTIC EDUCATION IN THE TEACHING OF GOD'S SERVANT - CARDINAL STEFAN WYSZYŃSKI}

For many contemporary parents and educators, patriotism is forgotten, unknown, foreign and sometimes deliberately depreciated and falsified reality. Much as patriotic education of contemporary Polish youth is an important ground of educational activity realised not only in family, pre-school, school and extracurricular environment, its contemporary understanding often undergoes semantic emasculation and attempts to alienate it from Polish national ethos. After the period of methodological indoctrination, whose aim was to subordinate the idea of loving one's own nation to ideologies of state power, we could notice the weakening interest in patriotism and detaching by many people from involvement in social issues. The offer of the socalled new European and American culture, which promotes education detached from homeland, nation, ethnicity, national culture, language and the entire diversity of virtues of native cultural heritage is also worth mentioning. The offer also provides depreciating evaluations for such values as: nation, homeland, religion or patriotism. Standing by the afore-mentioned values is repeatedly labelled as "narrow traditionalism" and becomes the reason for indiscriminate attacks from the representatives of opposition parties and other cultures and traditions. As a result of such behaviour, patriotism without properties is promoted. On this account the restoration of the appropriate place 
and comprehension for patriotic education of modern youth becomes particularly significant and relevant.

The recollection of the person and work of Cardinal Stefan Wyszyński, for whom "Poland was the highest value after God" is very supportive in this process. Heroic lesson of patriotism he was recurrently giving us and which he left us with, may be useful not only for Poles. Bearing in mind the primatial understanding and realisation of patriotic education, let us commence with portraying the meaning of this issue as well as with outlining the approaches and behaviours generated by this understanding. Subsequently, we will centre your attention on the genesis of patriotism comprehended in this way. The final part of the analysis will focus on the practical aspect of patriotic education and will offer an insight into a figure of cardinal Stefan Wyszyński as a teacher of Christian patriotism.

\section{PRIMATIAL UNDERSTANDING OF PATRIOTISM}

Analysing rich homiletic and literary heritage of firstly a priest, subsequently a bishop, a cardinal and the Primate - Stefan Wyszyński', the distinct impression occurs that most frequently he was combining a notion of patriotism with the emotional approach of bonds with one's own nation and its history as well as with the spiritual belonging to a community creating his homeland in the past, the present and

1 This heritage was and will remain the field of research of the author, which resulted in numerous publications. The most important ones are: Educating youth in the teaching of Cardinal Stefan Wyszyński, Lublin 1995 ed. I and 2001 ed. II; other very important publication is edited and selection of texts addressed by Primate of Poland to the community of the John Paul II Catholic University of Lublin, titled: For God and Homeland. The John Paul II Catholic University of Lublin in statements of Primates of Poland, Lublin 2008. Another publication resulting from the author's research was a post-conference publication issued by Scientific Society of the John Paull II Catholic University of Lublin, titled: Social need of recollection. The person and work of Cardinal Stefan Wyszyński Primate of the Millennium), Ed. A. Rynio, M. Parzyszek, Lublin 2017. 
the future. It was a bond with people, belonging to a homeland, with whom we were growing up in a family, school, in the nearest environment, with nature, with places in this homeland, with native literaturę, art and architecture, as well as with works of painting and music. Primatial understanding of patriotism requires emphasis, however, that love for homeland is not only a case of feeling or emotions. Indeed, it is associated with the realm of human emotional life but is not confined to it and obviously exceeds it. It occurs because S. Wyszyński derives patriotism from the history of the nation, from its culture, for which Christianity is the source. Thus, Poles should enhance their national identity, continually being aware who they are and where their roots are.

Primatial understanding of patriotism was identified with broadly defined attitude of love comprising God, man and homeland and that is why it should be analysed in cognitive, emotional and impact categories. The core of this attitude of love is homeland in its spatial, communal and cultural dimension. It is worth observing, however, that primatial patriotism grows out of love and reverence for parents and family. It appears as ,an extremely intelligent feeling”, moral duty, a set of civil virtues and worthy value. However, it is deprived of complacency and egoistically ,toned" pride of being a Pole or a representative of other nation. It rather stands out as a set of social virtues combined with the skill to pay respect a man should have toward this community, which brought them up, ergo their family, country and nation. A set of virtues comprises love for immediate family, who they live in a community, social justice inducing to select common good of a country over their own good and the aforementioned respect for the community, in which they grew up and from which they accepted customs aa a basis for spiritual life. The attitude manifesting patriotism, which is not only a privilege but an obligation, is also a broadly defined responsibility for one's homeland and for all it constitutes (nation, culture, religion, education, identity, heritage in loving a native land, freedom and solidarity, moral and social order, history of victorious and lost national uprisings and battles, suffering, remembrance about heroes, cooperation and peace, dignity 
of human work, protection of family and life of the unborn, personal role models, care about what currently is taking placing in one's homeland, love for Mother of God), which is reflected not only in words but in specific actions and activities.

Primatial patriotism is an acquired structure, similarly to other attitudes. It appears in human personality as the effect of interaction with their own social (family, school, Church, participation in outof-school organisations) and cultural environment. Upbringing plays a particularly important role here, in which, since the earliest years, there is a message of significant, native values of culture, moral norms, behaviour patterns and social activity. According to cardinal S. Wyszyński patriotic education of children and youth is one of the areas of integral education, comprising any intended influence on a pupil, made in a specific situation, to support them in generous and accurate development of genuine and active love for homeland with simultaneous cultivation of appropriately comprehended tolerance towards other nations and cultures. It is associated with the effort to know and love national culture and its spiritual values, shaping personality in accordance with the rules ordering life of homeland, creating cultural heritage, enhancing it and taking responsibility for it, so that this heritage could be transferred to subsequent generations. Because there are no authentic patriotic attitudes without knowledge of native history, defence of national traditions, love for native homeland, respect and development of national heritage or noticing connections between land and people, who created it and create it, leaving their own works and achievements in it. He was teaching that ,freedom was not a godsend" and was confidently defending the sense of national uprisings. In the face of totalitarianism of lack of ideological content and relativism, he was inviting the young to discovers the way to genuine freedom. Love for homeland was regarded by him as a natural obligation of each Pole, and he did not associate patriotism with chauvinism or erroneous nationalism. He also left an array of guidelines how we should love our homeland nowadays. He thought that "We do not need a heroic death of love today but rather heroic work for our Homeland". He was saying: "We 
are famous for the fact that we must sacrifice ourselves and give our life. Poles can die wonderfully, but, my dearest, we need Poles to be able to work wonderfully as well"'2.

\section{GENESIS OF PRIMATIAL UNDERSTANDING OF PATRIOTISM}

In his address to the Polish nation dated on 7 VII 1981, bearing witness to remarkable greatness of the Primate the Holy Father indicated his richness of the spirit demonstrated in love for the Church, homeland and $\operatorname{man}^{3}$. This richness was gradually achieved by the future Primate by the upbringing he obtained in his family home and education in a primary and secondary school, scouting, theological summary in Włocławek, the John Paul II Catholic University of Lublin, Odrodzenie community, formative work done among workmen, war experience, Laski community in the Warsaw region, meetings with outstanding people, not to mention his permanent auto formation exhibited throughout his entire life regardless of situations and circumstances.

However, Primatial understanding of patriotism was conditioned not only by personal experience, but by accepted anthropology and sociological-historical knowledge as well. In its light a man appears as autonomous being and simultaneously a concrete person, possessing attributes of brains, freedom, dignity, unalienable rights, living in a family, working in a nation. Human dignity is the highest value. It excludes the subjective treatment of oneself and others, provides them the content of fundamental moral norm ${ }^{4}$, which is love. In the teaching of the Primate, a man is regarded as compositum

2 As cited in A. Rastawicka, Marian ways of freedom by Primate of the Millennium. May readings, Warszawa 2018 , p. 65.

${ }^{3}$ Cf. The Holy Father John Paul II about Cardinal Stefan Wyszyński, in: An outstanding person, Warszawa 1984 p. 127-140.

${ }^{4}$ B. Piasecki, Last days of Primate of the Millennium, Kraków 2011, p. 152. 
of unity of body and soul, ${ }^{5}$ someone, who was created in the image and likeness of God - as an intelligent and free human being ${ }^{6}$. In his contemplations „Our Father” Cardinal Stefan Wyszyński was writing: ,a man (...) may overcome oneself, ,go through" oneself”... and „become sensitive to others"7. He appealed not to hold onto utilitarian individualism or nationalism. He called for social love. He emphasised how the skill of listening, attentiveness, sensitivity to human problems, needs of body and soul were important, but also acceptance of the other person in their so deserved right to disparity ${ }^{8}$. He referred his contemplations to personal, social, cultural, political or economic rights. In his works he was demonstrating the value of the right to live from the moment of conception until natural death. He was postulating the right to truth and freedom of conscience ${ }^{9}$. He emphasised that ,a man in the Nation lives not only for themselves and not only today, but also in the dimension of the nation's history"10. He was talking about strength of the Polish nation, which may live via its own powers, by its native culture enhanced by the Gospel ${ }^{11}$. He reminded us that there are spiritual roots of national and Christian identity and Polish culture in "Gniezno" at St. Adalbert's grave. ${ }^{12}$. He encouraged us to a brave sight into the future, rational judgement of reality and ambition to stand in the future ${ }^{13}$. He emphasised that Christianity entails power of the spirit and heart. He used to say:

5 S. Wyszyński, Our Father. Contemplations, Warszawa 2001, p.72.

6 A. Fudali, Cardinal Stefan Wyszyński, Social reformer, in: Social need for remembrance. The person and work by Cardinal Stefan Wyszyński Primate of the Millennium, ed. A. Rynio, M. Parzyszek, Lublin 2017, p. 338 and other pages.

7 S. Wyszyński, Our Father. Contemplations, p.11.

8 B. Piasecki, Last Days of Primate of the Millennium, op. cit., p. 159-165.

9 A. Jasiński, Cardinal Stefan Wyszyński - witness of faith, part 1, Gniezno 1999, p. 110-113.

10 B. Piasecki, Last Days of Primate of the Millennium, op. cit., p. 10-11.

11 P. Raina, Cardinal Wyszyński - prison fate, Warszawa 1994, p. 11.

12 B. Piasecki, Last Days of Primate of the Millennium, op. cit., p. 131.

13 A. Jasiński, Cardinal Stefan Wyszyński-witness of faith, op. cit., p. 81, 82. 
"Fight evil with good” ${ }^{14}$. He was completing these words with: „Future belongs to those who love, but not to those who hate"15.

Primatial patriotic education was based on biblical foundation, tradition and understanding who a man is, what they desire and what they are created with. It may be confirmed both by the very way of defining the phenomenon of bringing up a person and by means of the ways of the inclusion of their planes, objectives, rules and measures applied. The starting point for the activity of patriotic education is experience of educators and learners - thanks to which they understand who they are and what they should do in different life circumstances.

Primatial view of patriotic education had its rudimentary significance for shaping the appropriate attitude towards themselves, God, as well as towards public and social relations. By his approach he was teaching patriotism through love to all that was Polish. He had, during that, remarkable respect towards people, language, native culture and nature. He was paying attention not only to basic forms of social life such as family, nation or country, but also to reason for being of a community residing in openness of human nature and the reason for the sense of social life, which is a category of common good and moral order.

Three truths, which constitute a structure of his teaching in each dimension, seem to dominate among content-related themes of Primatial patriotic contemplations. The issue concerns the truth about ,adored God, respected man and served land” taken from St. Augustine. Interpermeating and complementing dimensions and planes may be easily noticeable in Primatial education. The personal, social and religious dimensions are particularly observable. The ontological, ethical-axiological, cultural or theological dimensions

14 S. Wyszyński., Our Father. Contemplations, op. cit., p. 51.

15 S. Wyszyński, Prison notes, Ząbki 2006, p. 357. 
are demonstrated as well, which was described in detail in my postdoctoral monograph ${ }^{16}$ and in other studies ${ }^{17}$.

As the Primate, emphasising a programme of social education of youth, which was not depreciating patriotic education at all, he was making his listeners aware, that upbringing should commence most of all from socialising oneself. It was coming down to socialising one's feelings, thinking, desires, mind, work, will, vocation and profession.

It was meant to feel, think, desire and work socially ${ }^{18}$ having at the same time an appropriate attitude to work understood as an activity relevant for a human being and necessary for their full development ${ }^{19}$; so that they could learn to live their life in respect for personal, foreign and social property ${ }^{20}$, and being aware of their own insufficiency, they should live by their belonging to a familial, professional, national and transnational community, as well as to their political and religious community ${ }^{21}$.

${ }^{16} \mathrm{Cf}$. A. Rynio, Education of youth in the teaching of Cardinal Stefan Wyszyński. Lublin 1995 ed. I, Lublin 2001 ed. II.

17 Compare, among others, A. Rynio, Education for responsibility for a nation in Millennial Sermons of Cardinal Stefan Wyszyński, Lublin 1979, p. 229-239; Id., Social education of a person in the teaching of Primate of the Millennium, in: Catholic pedagogy. Selected issues, ed. A. Rynio, Stalowa Wola 1999 p. 215-242; Id., Intelligent patriotic education as subject of concern by Primate of the Millennium, "Primatial Studies" 5(2011) p. 247-264; Id., Pedagogical thought of Cardinal Stefan Wyszyński, in: S. Fel, M. Wódka (ed.), Cardinal Stefan Wyszyński (1901-1981), Social thought, Lublin 2017, p. 47-70; Id., Education of youth in the pastoral ministry of Stefan Wyszyński, in: Social need for remembrance. The person and work by Cardinal Stefan Wyszyński, Primate of the Millennium, ed. A. Rynio, M. Parzyszek, Lublin 2017 p. 237-257.

18 „Other people have the right to what you have and what you can. Social duties weigh heavily on our social competences and life skills. Our profession, specialisation are not only our services (...)We are supposed to live not only for ourselves, but also for God, Homeland, for our family and our neighbours". S. Wyszyński, Sermons and authorised speeches, 1975, vol. 52, p. 192; compare also 1957 vol. 2, p. 37

19 Pastoral letters of Primate of Poland and Polish Bishops' Conference, 19471974, Paris 1975 p. 758.

20 S. Wyszyński, Sermons and authorised speeches, 1958 vol. 4 p. 84.

${ }^{21}$ Ibidem, p. 69. 
This belonging was supposed to be based on familiarity and taking responsible actions in favour of other people and the aforementioned communities. Wyszyński was teaching that individual upbringing in itself, not being separated from social education, cannot be a pedagogical goal ${ }^{22}$.

In the face of ongoing discussion related to the purpose of education Primate Wyszyński supported the view that education should be oriented towards both a unit and a society, which a given unit lives in ${ }^{23}$. This standpoint protected from extreme individualism, as well it was far from, ,self-sacrifice” for society. In both cases it protected human dignity. Education of a person based on ethics was not conducted in separation but based on human nature and their destiny ${ }^{24}$.

Personal human development, with their individual features and properties as well as with the destination of their social nature should be taken into consideration as well. A man brought up in this way finds their place, knows their rights and fulfils duties both in their personal and social life ${ }^{25}$.

\section{CARDINAL STEFAN WYSZYŃSKI AS A TEACHER OF CHRISTIAN PATRIOTIC EDUCATION}

As an educator, the Primate was a strong, harmonious and loving individual. He wanted to be close to those who he was teaching, he wanted their growth, respected their freedom, he saw them in

22 Cf. S. Wyszyński, Mission statements of encyclical on Christian education of youth, "Priestly Ateneum" 26:1930 p. 8.

23 Ibidem, p. 9; Archives of the Primatial Institute of Cardinal Stefan Wyszyński. S. Wyszyński, The right of family, Church and state to school. Lublin 1929, typescript; Id., In case of Catholic education of youth, in: Pastoral Letters of Primate of Poland, Id., p.173; Id., The problem of Christian education of youth, "Working Papers of The John Paul II Catholic University of Lublin” 12:1969 no. 2 (46) p. 15.

24 Ibidem.

25 AIPSKW, S. Wyszyński, Sermons and authorised speeches, 1961, vol. IX, p. 232. 
a realistic way. While teaching, Wyszyński attempted to help people in their authentic discovery of their own richness within their intellect, will and feelings. Since the beginning of his priestly and literary activity, an effort aiming at understanding the world of youth was highly observable ${ }^{26}$.

Wyszyński understood one of the ways to educate a man, a citizen and a saint in making his learners resistant to untruth, evil and ugliness and teaching them a reliable differentiation of values from what is opposite to them. Teaching self-reliant thinking and appropriate valuating, he did not leave young people with their doubts. He was referring to indestructible values combining mind, will and heart. In human relations he was advising "to overcome oneself".

As far as patriotic education is concerned, Priest Wyszyński saw one of its basic objectives in teaching a sense of responsibility for a nation and all this which is constitutes its value. While analysing the content of primatial speeches, it is noticeable that Wyszyński regarded a basic expression of a sense of responsibility for a nation in educating a young person to comprehensive development of their personality. The main assumption here was a mature personality. Responsibility was supposed to be its expression. This education, comprising the entire man, was supposed to be in the first place education for a responsible life in belief in everyday life.

Being aware of significance of a culture phenomenon, as well as seeing one of the basic elements of historic mission of a nation, Primate repeatedly voiced his concern about honesty of this message. Hence, in a repository of history, with simultaneous creation of culture, he saw a foundation in the present to build the future. ${ }^{27}$. It is understandable, because Wyszyński treated a national culture as heritage of generations and indisputable property of the entire nation.

26 Cf. The Holy Father John Paul II about Cardinal Stefan Wyszyński, in: An outstanding person, Warszawa 1984 p. 127-140.

27 AIPSKW, S. Wyszyński, Authorised sermons and speeches of a millennial trail from Gniezno 14 IV 1966 to Łomża 7 VIII 1966, vol. I, 1966, p. 161, typescript. 
He noticed three basic tasks, the fulfilment of which is an obligation toward a nation an expression of responsibility. These are: honest message for young generations of everything which constitutes family culture, its defence and the creation of new cultural values in the present. Primate was convinced that history of a nation, world of spiritual experiences and power of age experiences, by means of which a nation utters the contents of its life, constitute a foundation for further creation of culture ${ }^{28}$.

That is why while making young people aware of the value of the past „sometimes painful and hard, but eventually successful and victorious" 29 he advised to be careful in evaluating $i^{30}$. What is more, he demanded humility, worship and respect for the past ${ }^{31}$. He advised to talked about it in a just way and with concern about truth. He demanded a good knowledge of history, understanding and love of each excerpt of native history, from which he urged to abstract all that results from the right of love and justice ${ }^{32}$.

What is worth noting here is the fact that Primate Wyszyński not being shocked by sins of the past and even seeing ,a blessed lesson for future generations" among historical sufferings and failures, ${ }^{33}$ he definitely warned the young against building on the errors from the past ${ }^{34}$.

In Priest Wyszyński's opinion education in faithfulness towards a native culture should be expressed not only in respecting the past by the present, but mostly in educating young generations in almost a religious cult for all gifts of nature and grace, which united and strengthened a nation ${ }^{35}$. Wyszyński did not see the chance to build the future without fulfilling this condition. Indicating the previous

\footnotetext{
28 Ibidem, p. 138, 184.

29 Ibidem, p. 81.

30 Ibidem, p. 184.

31 Ibidem, p. 383.

32 Ibidem.

33 Ibidem, p. 93.

34 Ibidem, p. 383.

35 Ibidem.
} 
generations, which at the price of the biggest sacrifices transferred the history of a Catholic nation, a Christian lifestyle, customs and all which constitutes culture, he made his listeners aware that they are their debtors and continuators ${ }^{36}$.

In numerous statements, with a view to different aspects of a national culture, he paid special attention to a culture of religious, familial and social life. Not depreciating the value of material achievements and welfare, in which he saw "means, tool and essential material" of culture, Primate set a task for the young to permeate matter with a culture of spirit. It was a condition so that achievements and prizes of young people could deserved to be labelled as permanent and timeless ${ }^{37}$.

Other task the youth faces, in the fulfilment of which one of the basic dimensions of a sense of justice and responsibility towards a native community was its concern about a nation's life. This problem was specified by Wyszyński to such an extent that he equated a nation's life with defence of life of a conceived child. It is particularly noticeable in the sermons of The Great Novena.

Education in the vein of responsibility for a nation and the future of entire society also imposed an obligation on young people to prepare well for the future family and professional life. By demonstrating the need to educate in responsibility for a nation, Wyszyński called for a spirit of sacrifice and offering, without which we cannot talk about a good fulfilment of a Christian obligation. Calling for a generation of "new people", he encouraged them to overcome selfishness, egoism and love for an easy life ${ }^{38}$.

It seems that achieving this „novelty" was coming down, consequently, to a responsible life in faith in the dimension of a personal and social life was the most frequently promoted way of accomplishing responsibility. Not diminishing the heroic examples

36 Ibidem, p. 160.

37 S. Wyszyński, From considerations over a native culture, Poznań -Warszawa 1979, p. 97-98.

38 Ibidem, 1966 vol. I p. 375; vol. II p. 9, 192. 
of sacrifice, love, sobriety and persistence, Wyszyński was teaching his contemporaries, so that they should be governed by responsibility based on God's law expressed in ten commandments and evangelic blessings and in the afore-mentioned principle of common good, subsidiarity and solidarity. It is not difficult that it was education of a young generation in the vein of profound understanding of truth of the faith and Christian morality expressed in community and community-creating thinking and acting ${ }^{39}$.

Primate Wyszyński cared about socialising juvenile religious ideals ${ }^{40}$, awakening a desire of social Christian virtues, a familiarisation of the principles of social ethics and conveying to youth, that justice is possible in the world without rape, prisons, concentration camps, bloodshed or modern slavery, exploitation of human work" ${ }^{\prime 41}$.

It is also worth noticing at the end that such comprehended patriotic education is achieved through authority, a meeting with witnesses, a dialogue and suffering; it assumes a subjective-personal activity, a reference to the so-called objective requirements (truth, subjectivity, good and beauty); he transparently need a participation of family, school, state and Church. Informal groups and pedagogical communities take part in it as well (national, church communities, religious movements, organisations and associations). A considerable role was played by means of social message, which were not ignored by Primate. However, these are the issues which require a separate study.

\begin{abstract}
The presented text is an attempt to demonstrate understanding and realisation of patriotic education in the teaching of Cardinal Stefan Wyszyński Primate of Poland It brings closer the significance of the very notion as well as it demonstrates attitudes

39 Ibidem, 1970 t. XXXIV, p. 269.

40 Pastoral Letters of Primate of Poland 1946-1974, Paris 1975, p. 130.

${ }^{41}$ Ibidem.
\end{abstract}


and behaviours generated by this understanding. The publication focuses our attention on the genesis of such comprehended patriotism and education. The final part of the analyses concerns the practical aspect of patriotic education and brings closer the figure of Cardinal Stefan Wyszyński as a teacher of a Christian view on education, Polish nature and Poles. What results from the conducted analyses and observations is the fact that remembrance and familiarity with a pedagogical message of Cardinal Stefan Wyszyński - a remarkable Primate of the Millennium concerned about ethical-moral foundations of social life, may assist contemporarily living nations and people, and generations of Poles, in particular and those who will be their continuators - in preserving identity in the personal, social, national, cultural and ecclesiastic dimensions.

Keywords: patriotism, Stefan Wyszyński, education, nation, homeland

\section{Bibliography}

Archival sources

Archives of the Primatial Institute of Cardinal Stefan Wyszyński

Wyszyński S., Authorised sermons and speeches of a millennial trail from Gniezno

14 IV 1966 to Łomża 7 VIII 1966,, vol. I, II, 1966, typescript.

Wyszyński S., Sermons and authorised speeches, vol. I- LXVII, typescript.

Wyszyński S., The rights of family, Church and state to school. Lublin 1929, typescript.

Printed sources

For God and Homeland. The John Paul II Catholic University of Lublin in statements of Primates of Poland, Selection and edition: A. Rynio, J.Gawrysiakowa, M. Butkiewicz, Lublin 2008.

Letter of Polish Bishops' Conference on Christian patriotism, Poznan 5 IX 1972, in: Pastoral Letters of Polish Bishops' Conference 1945-1974, Paris 1975.

Pastoral Letters of Primate of Poland 1946-1974, Paris 1975.

The Holy Father John Paul II about Cardinal Stefan Wyszyński, in: An outstanding person, Warszawa 1984.

Wyszyński S., For those stepping into the future, Warszawa 1986.

Wyszyński S., One is Poland, Warszawa 1989.

Wyszyński S., Our Father. Contemplations, Warszawa 2001.

Wyszyński S., The problem of Christian education of youth. „Working Papers of The John Paul II Catholic University of Lublin” 12:1969 no. 2 (46). 
Wyszyński S., Mission statements of encyclical on Christian education of youth, "Priestly Ateneum" 26:1930.

Wyszyński S., In the heart of the capital, Rome 1972.

Wyszyński S., In case of Catholic education of youth, in: Pastoral Letters of Primate of Poland 1946-1974, Paris 1975.

Wyszyński S., Prison notes, Ząbki 2006.

Wyszyński S., From considerations over a native culture, Poznań -Warszawa 1979.

Studies

Fudali A, Cardinal Stefan Wyszyński, Social reformer, w: Social need for remembrance. The person and work by Cardinal Stefan Wyszyński Primate of the Millennium, A. Rynio, M. Parzyszek (ed.), Lublin 2017.

Jasiński A., Cardinal Stefan Wyszyński-witness of faith, part 1, Gniezno 1999.

Piasecki B., Last days of Primate of the Millennium, Kraków 2011.

Raina P., Cardinal Wyszyński- prison fate, Warszawa 1994.

Rastawicka A., Marian ways of freedom by Primate of the Millennium. May readings, Warszawa 2018.

Rynio A., Intelligent patriotic education as subject of concern by Primate of the Millennium, "Primatial Studies" 5(2011).

Rynio A., Pedagogical thought of Cardinal Stefan Wyszyński, in: S. Fel, M. Wódka (ed.), Cardinal Stefan Wyszyński (1901-1981) Social thought, Lublin 2017.

Rynio A., Social education of a person in the teaching of Primate of the Millennium, in: Catholic pedagogy. Selected issues, ed. A. Rynio, Stalowa Wola 1999.

Rynio A., Education of youth in the teaching of Cardinal Stefan Wyszyński, Lublin 1995 ed. I and 2001 ed. II.

Rynio A, Education for responsibility for a nation in Millennial Sermons of Cardinal Stefan Wyszyński, Lublin 1979.

Rynio A., Education of youth in the pastoral ministry of Stefan Wyszyński, in: Social need for remembrance. The person and work by Cardinal Stefan Wyszyński, Primate of the Millennium, ed. A. Rynio, M. Parzyszek, Lublin 2017.

Social need for remembrance. The person and work by Cardinal Stefan Wyszyński, Primate of the Millennium: ed. A. Rynio, M. Parzyszek, Lublin 2017.

\section{Author's biodata}

Alina Rynio, associate professor, head of Chair of Christian Pedagogy of The John Paul II Catholic University of Lublin, specialises in a broadly defined 
theory of education. While interpreting the message of such outstanding thinkers as Cardinal Stefan Wyszyński, John Paul II, priest Ligi Giussani, she deals with searching for contemporarily relevant forms and ways of forming mature, free and responsible personality. 